\author{
Iwona Król \\ Uniwersytet Jagielloński \\ iwona.krol@uj.edu.pl \\ ORCID: 0000-0002-0151-3559
}

\title{
TABU JĘZYKOWE W ARABSKICH PRZEKŁADACH BIBLII
}

DOI: http://dx.doi.org/10.12775/RP.2021.005

\begin{abstract}
Zarys treści: Niniejszy artykuł przedstawiający wybrane rozwiqzania translatorskie obecne we współczesnych przekładach tekstów biblijnych na język arabski stanowi poszerzenie badań Marka Pieli dotyczących przekładów Biblii hebrajskiej na język polski. Przeprowadzone przeze mnie analizy dotyczą głównie strategii przekładu wyrazów i wyrażeń należących do sfery tabu, przy czym skupiam się na takich aspektach, jak: dosłowność, dokładność, idiomatyczność, adekwatność stylistyczna czy ewentualne zniekształcenia sensu.
\end{abstract}

Słowa kluczowe: Biblia, przekłady Biblii na arabski, tabu językowe, eufemizmy, wulgaryzmy

\section{Wstęp}

$\mathrm{H}$ ebrajski i arabski należą do tego samego semickiego odgałęzienia rodziny języków afroazjatyckich, jednak odmienność ich procesów rozwojowych zaowocowała wystąpieniem pomiędzy nimi znacznych różnic. Arabski język literacki (al-luğa al-'arabiyya al-fuṣhāa) funkcjonujący głównie w odmianie pisanej nie uległ istotnym przemianom - zwłaszcza w zakresie składni i morfologii - od okresu klasycznego, zapoczątkowanego przez powstanie islamu i jego księgi, Koranu. Pozostawał również relatywnie odporny na zapożyczenia, sam natomiast stanowił źródło zapożyczeń dla języków, którymi posługiwali się muzułmanie niearabscy, zwłaszcza mieszkający na terenach pozostających pod panowaniem imperium arabsko-muzułmań- 
skiego. Dotyczyło to nie tylko słownictwa religijnego, lecz także leksyki związanej z innymi dziedzinami kultury, literatury i nauki (Versteegh 1997: 226-239). Można tu dostrzec pewną analogię do języka hebrajskiego, który przez około 2000 lat również pozostawał w miarę jednolity, zapewne także dlatego, że był językiem pisanym. Należy podkreślić, że biblijny język hebrajski to język martwy, natomiast współczesna arabszczyzna literacka, tylko w niewielkim stopniu pełniąca funkcję medium komunikacji ustnej (przede wszystkim w środkach przekazu), nawet przez jej rodzimych użytkowników jest odbierana jako w gruncie rzeczy koturnowa i nieekspresyjna, przez co partie dialogowe $\mathrm{w}$ tekstach literackich często formułowane są $\mathrm{w}$ dialektach (Danecki 2000: 34-35).

Przytoczone fakty przemawiają za tym, że badanie współczesnych przekładów Biblii hebrajskiej na arabski pod kątem stosowanych w nich strategii translatorskich może dostarczyć inspirujących obserwacji i wniosków. Zacznijmy od spostrzeżenia, że stosowanie w tłumaczeniach na arabski literackiej odmiany tego języka można potraktować jako strategię analogiczną do tak wyraźnego w przekładach polskich ciążenia ku archaizacji. Zauważmy przy tym, że nie ma kompletnych przekładów Biblii na dialekty arabskie. Istnieją jedynie lekcjonarze - czyli zbiory czytań biblijnych - np. w dialekcie libańskim czy egipskim, a także przekład Ewangelii na dialekt algierski ${ }^{1}$. Takie dialektalne wersje są dostępne w Internecie, jako teksty pisane lub nagrania, jednak jest ich niewiele ${ }^{2}$. W przekładach biblijnych nie stosuje się powszechnych w tekstach literackich (zwłaszcza w powieści i nowelistyce) rozwiązań polegających na włączaniu do tekstu w odmianie literackiej fragmentów w dialekcie.

Pierwsze tłumaczenia Biblii hebrajskiej (dokonane w okresie przedchrześcijańskim) były dziełem samych Żydów. Najstarsze i najbardziej znane to grecka Septuaginta powstała pomiędzy III a I w. p.n.e. na użytek posługujących się językiem greckim Żydów egipskich (Majewski 2013: 13). Najstarsze tłumaczenia Biblii na język arabski datują się na koniec VII lub początek VIII wieku (Griffith 2013: 127). Język arabski uzyskał wówczas status języka literackiego oraz sformalizowano jego gramatykę, głównie ze względu na potrzebę skodyfikowania tekstu Koranu, a także opracowania

1 Zob. https://ebible.org/arq/ (dostęp: 30.03.2021).

2 Np.przekład Ewangelii św. Marka oraz opowieści o prorokach w dialekcie tunezyjskim: https://www.maarifa.org/index.php?option=com_content\&view=article\&id=3504\&Itemid=232 (dostęp: 30.03.2021). 
jego wykładni. Arabski stał się również językiem urzędowym oraz lingua franca na terenach należących do arabsko-muzułmańskiego imperium. Przekładów Biblii na arabski dokonywali wówczas chrześcijanie posługujący się na co dzień różnymi dialektami języka arabskiego, dla których językiem oficjalnym, posiadającym normę gramatyczną i ortograficzną, był literacki język arabski używany niemal wyłącznie w odmianie pisanej. Przekłady judeo-arabskie, dokonywane przez Żydów na użytek arabskojęzycznych wyznawców judaizmu, zaczęły powstawać w IX wieku, a najważniejsze z nich to tłumaczenie Saadii Gaona (Griffith 2013: 124). Były zapisywane alfabetem hebrajskim bez wokalizacji, co niezmiernie utrudniało ich lekturę, gdyż w hebrajskim występuje mniej spółgłosek (niekiedy różnicowano je za pomocą znaków diakrytycznych przejętych z arabszczyzny) (Khan 2006: 528). Natomiast współczesne tłumaczenia Biblii na arabski to wyłącznie tłumaczenia chrześcijańskie.

W tym kontekście warto także zauważyć, że podejście wyznawców poszczególnych religii monoteistycznych do swych świętych ksiąg, języka lub języków, w których zostały one spisane, a także do tłumaczenia ich na inne języki było bardzo różne. Dla ortodoksyjnych Żydów jedynie język hebrajski ma charakter języka świętego, dlatego inne wersje językowe miały niższy status niż Biblia hebrajska. Przekłady na arabski określano słowem tafsīr, czyli ‘komentarz', w założeniu bowiem miały być tylko pomocą dla Żydów nieznających języka Biblii w stopniu dostatecznym. Skoro jednak Bóg przemawia do ludzi - za pośrednictwem natchnionych autorów - w ich języku i w konsekwencji język tekstów biblijnych nie różni się zasadniczo od języka innych tekstów literackich tej samej epoki, dopuszczano przekład Biblii na inne języki. Opierając się na podobnej zasadzie, niektórzy współcześni teoretycy przekładu postulują, aby język tłumaczeń Biblii nie różnił się zasadniczo od języka współczesnych im tekstów literackich (Piela 2007: 236).

Z kolei Arabowie, w większości muzułmanie, za język święty uważają wyłącznie język arabski, ponieważ Koran - święta księga islamu, której arabski oryginał znajduje się w niebie - został objawiony Mahometowi za pośrednictwem archanioła. Proroka Mahometa nie uznaje się zatem za jej autora. Nie spisał on także swoich objawień, a jedynie przekazał je ustnie. Stąd bierze się kategoryczny zakaz tłumaczenia Koranu na inne języki, a istniejące przekłady są traktowane jedynie jako interpretacje (Pearson 1986: 429). Tylko dla chrześcijan teksty Starego i Nowego Testamentu pozostają święte zarówno w językach oryginalnych, jak i w tłumaczeniach. 
Właśnie kwestia językowego sacrum sprawia, że tak ważne są zasady stosowane podczas przekładu. Według Marka Pieli jednym z kluczowych zagadnień jest $\mathrm{w}$ tym zakresie wybór między tłumaczeniem słowa na słowo a tłumaczeniem sensu na sens, co we współczesnej teorii przekładu (np. E.A. Nida, Ch.R. Taber) określa się jako wybór między ekwiwalencją formalną - czyli przekładem dosłownym - a ekwiwalencją dynamiczną (funkcjonalną) - czyli przekładem dążącym do wierności na zasadzie podobieństwa oddziaływania na odbiorcę (Piela 2003: 9-10).

W Biblii znajdujemy wiele przykładów funkcjonowania tabu językowego, czyli „społecznie usankcjonowanego zakazu mówienia o czymś lub wypowiadania pewnych wyrazów" (Krawczyk-Tyrpa 2001: 14). Wydaje się, że słownictwo należące do sfery tabu wymaga od tłumacza użycia szczególnie przemyślanych strategii translatorskich, stąd jego wybór jako przedmiotu analizy. Obejmie ona po pierwsze hebrajskie eufemizmy, a po drugie hebrajskie wulgaryzmy oraz sposoby ich oddawania w arabskich wersjach Starego Testamentu.

W niniejszym artykule posłużę się następującymi tłumaczeniami Biblii na język arabski: (SvD) Smith and van Dyke Arabic Bible, 1865, w wydaniu z 1998 roku; (JAB) Jesuit Arabic Bible, 1880, w wydaniu z 1986 roku; (LAB) Arabic Life Application Bible w wydaniu z 2002 roku; (GNA) Good News Arabic Bible w wydaniu z 1995 roku; ERV-AR: Arabic Bible: Easy-to-Read Version - wersja internetowa. Są to przekłady współczesne, w większości dwudziestowieczne, a dwa najstarsze: SvD oraz JAB powstały w okresie po rozpoczęciu tzw. współczesnego odrodzenia arabskiego (an-nahda al-'araibiyya al-hadīta), kiedy po wielu wiekach regresu kultury arabskiej zaczął kształtować się współczesny arabski język literacki.

W analizie przywołam także kilka polskich przekładów Biblii, o ile stosuje się w nich strategie tłumaczeniowe zbieżne $\mathrm{z}$ tymi, które są obecne w przekładach na język arabski. Są to głównie: Biblia Tysiąclecia, wyd. 3, 1980, oraz jeden z najnowszych (2008) całościowych przekładów Biblii - Biblia Paulistów - który w założeniu ma być wiernym przekładem na współczesną polszczyznę (BPau: 9). 


\section{Hebrajskie eufemizmy}

W biblijnym hebrajskim tabuizacji podlegały m.in. wyrazy i wyrażenia związane ze sferą sacrum (imię Boga, Jahwe), a także takie, które nazywały niektóre części ciała czy też czynności fizjologiczne, głównie seksualne (Ellingworth, Mojola 1986: 139). W celu ich uniknięcia posługiwano się różnego rodzaju językowymi środkami eufemizacji (Ellingworth, Mojola 1986: 142-143).

\subsection{Tabu zwiq̨zane ze sferq̨ sacrum}

\section{jhwh 'Jahwe'}

W judaizmie imię Boga - Jahwe objęte jest tabu. Żydzi nie mogli go wymawiać przez wzgląd na jego świętość. Gdy Mojżesz pyta Boga, co ma odpowiedzieć Izraelitom, kiedy zapytają o Jego imię (Wj 3, 13), Bóg odpowiada: Ehyeh ('jestem') (Wj 3, 14), a następnie nakazuje Mojżeszowi, by oznajmił swemu ludowi, że posyła go Jahveh ('jest') (Wj 3, 15). W Wj 6, 2-3 Bóg ponownie wypowiada przed Mojżeszem swoje imię: Jahveh oraz zapewnia, że imienia tego nie ujawnił wcześniejszym patriarchom. Otrzymujemy tutaj zatem dwie wersje imienia Boga: pierwsza to czasownik 'być' w 1. osobie, a druga (częściej pojawiająca się w Biblii w funkcji boskiego imienia) to ten sam czasownik w 3. osobie. W tekście hebrajskim imię to zapisywano za pomocą właściwych dla niego spółgłosek ( $j h v h)$, natomiast wokalizowano je za pomocą samogłosek występujących w słowie Adonaj, 'mój pan' [dosł. 'moi panowie' pluralis maiestatis], które stanowiło substytut imienia Bożego, i to właśnie ono było odczytywane w trakcie głośnej lektury Biblii zamiast objętego tabu imienia Jahveh (Ellingworth, Mojola 1986: 139). Inny zastępnik zakazanego imienia to słowo Elohim.

W arabskich tłumaczeniach wersetów Wj, w których w Biblii hebrajskiej pojawia się forma w 1. osobie, Ehyeh, znajdujemy jej transkrypcję na język arabski ('Ihyih) uzupełnioną o ujęte w nawias dosłowne tłumaczenie znaczenia tego imienia na arabski: 'anā al-kä in ad-däim, jestem (tym, kto) zawsze jest" (SvD, LAB), 'anā huwa al-lad huwa man huwa, ,jestem tym, kto jest” (JAB) lub transkrypcję hebrajskiego zdania: 'ihyih 'ašir 'ihyih ,jestem, który jestem” (ERV-AR).

$\mathrm{W}$ arabskich tłumaczeniach wersetów $\mathrm{Wj}, \mathrm{w}$ których w Biblii hebrajskiej pojawia się forma w 3. osobie (Jahveh), stosuje się (np. Wj 6,3) arabską 
transkrypcję imienia Jahveh: Yahwah (SvD, GNA, ERV-AR), uzupełnioną niekiedy o wyjaśnienie, że oznacza ono: $A r-r a b b$ 'Pan' (LAB). Alternatywnym rozwiązaniem (GNA, JAB) jest zastąpienie hebrajskiego imienia Jahveh arabskim leksemem Ar-rabb 'Pan' (np. Wj 3, 15).

W przypadku wersetów, które nie objaśniają znaczenia imienia Jahveh, a samo imię służy jedynie identyfikacji bóstwa, arabskie tłumaczenia stosują leksem Ar-Rabb 'Pan' (np. Wj 34, 14, Pwt 5, 9).

Arabscy tłumacze przestrzegają zatem żydowskich zasad tabu językowego, zastępując najczęściej imię Jahveh rzeczownikiem Ar-rabb 'Pan'. Arabska transkrypcja imienia Boga (Yahwah) pojawia się właściwie tylko wtedy, gdy towarzyszy temu metajęzykowy komentarz definiujący jego znaczenie.

\subsection{Tabu zwiq̨zane z czynnościami seksualnymi}

\section{gillå 'eruna / kånåf'odsłonić czyjąś nagość / 'zdjąć z kogoś ubranie’} Wyrażenie to występuje $\mathrm{w}$ dwóch wariantach leksykalnych, ponieważ dopełnieniem bliższym hebrajskiego czasownika drugiej klasy gillå (etymologicznie, a także po części znaczeniowo odpowiadającego arabskiemu ğallā; Wehr 1976: 132, zob. BDB: 162, s.v. gålå) może być rzeczownik oznaczający to, co odkrywane, obnażane (tu 'erua 'nagość, ar. 'awra), lub też rzeczownik oznaczający zdejmowaną, usuwaną zasłonę (tu kånåf 'ubranie', ar. kanaf 'strona,' bok'; 'skrzydło'; 'kryjówka'; Wehr 1976: 843). Idiom ten ma charakter metonimii i stanowi eufemistyczne określenie (BDB: 789, s.v. 'erua a, p. 1) współżycia seksualnego, przy czym „odsłonięcie nagości” odnosi się zwykle do obnażenia ciała podczas samego aktu, lecz niekiedy (np. Kpł 20, 11) może chodzić o „obnażenie” mężczyzny, z którego żoną się współżyje. Drugie ze wskazanych znaczeń tłumaczy się na dwa sposoby. Po pierwsze nagość żony, a zatem i jej ubranie stanowią wyłączną własność męża, który jako jedyny ma prawo ją obnażyć i w tym właśnie sensie jest to „nagość / ubranie ojca”. Natomiast zgodnie $\mathrm{z}$ drugą interpretacją Biblia wskazuje w ten sposób, że obcowanie cielesne z żoną ojca jest równoznaczne z obcowaniem cielesnym $\mathrm{z}$ nim samym i jako takie - równie godne potępienia ${ }^{3}$.

3 Zob. Piela 2003: 171-175 i literatura tamże, a zwłaszcza cytowany przez Pielę komentarz Jeffreya H. Tigaya do Pwt 23, 1 i Walthera Zimmerliego do Ez 22, 10. 


\section{gillå 'eruna 'odsłonić czyjąś nagość'}

Arabskie przekłady proponują literalne tłumaczenie tego idiomu, przy czym jego arabski ekwiwalent oznacza „odsłanianie miejsc intymnych (takich, które muszą być zakryte podczas wypełniania obowiązków religijnych czy w obecności innych osób - Al-Absi 2018: 27)", co w języku arabskim, w który wpisana jest aksjologia islamu, przedstawiane jest jako grzeszne, zabronione (harām), natomiast nie implikuje związku z czynnościami seksualnymi. Stosuje się tu czasownik kašafa lub jego synonim o tym samym rdzeniu w klasie VIII iktašafa, którego dopełnieniem bliższym jest rzeczownik 'awra 'nagość' (o takim samym rdzeniu jak hebr. 'erua ). Należy przy tym zauważyć, że nie pojawia się w tym kontekście - czego być może należałoby się spodziewać - czasownik ğallā będący etymologicznym i semantycznym odpowiednikiem hebrajskiego czasownika gillå. Tłumacze arabscy dokonali zatem deleksykalizacji hebrajskiego idiomu, oddając przy tym jedną z jego składowych za pomocą czasownika, który jest współcześnie w bardziej powszechnym użyciu.

\section{iktašafa (kašafa) 'awrata-hu 'odkrywać (czyjąś) nagość'}

Kpł 18, 7 (GNA) lā takšif 'awrat 'abikka bi-kašf'awrat 'ummika „Nie odkrywaj nagości swojego ojca poprzez odkrywanie nagości swojej matki”.

Kpł 18,7 (SvD) 'awrat 'abīka wa-'awrat 'ummi-ka lā takšif „Nagości swojego ojca i nagości swojej matki nie odkrywaj”.

Kpł 18, 6 (JAB) lā yaqtarib 'ayy rağul min d̄àt qarābati-hi li-yakšif'awrata-ha „Żaden mężczyzna nie będzie zbliżał się do swojej krewnej, aby odkryć jej nagość" (w przypisie znajdujemy wyjaśnienie, że ,jest to wskazanie na stosunki seksualne" [s. 260], bez którego wyrażenie to nie jest w pełni zrozumiałe).

Podobne rozwiązania znajdujemy w przekładach polskich Kpł 18, 7:

(BT) „Nie będziesz odsłaniać nagości swojego ojca lub nagości swojej matki".

(BPau) „Nie odsłonisz nagości swojego ojca, współżyjąc ze swoją matką”.

\section{gillå kånåf 'zdjąć z kogoś ubranie’}

Wśród tłumaczeń na język arabski znajdujemy rozwiązanie analogiczne do przekładu BT, gdzie hebrajskie wyrażenie tłumaczy się dosłownie, a „zdejmowaną rzeczą" jest brzeg płaszcza: „Nikt nie poślubi żony swego ojca i nie odkryje brzegu płaszcza ojca swego” (Pwt 23, 1); „Przeklęty, kto obcuje 
cieleśnie z żoną swego ojca, gdyż odkrywa brzeg płaszcza swojego ojca” (Pwt 27, 20).

W JAB użyto wyrażenia: naza'a dayl ridä'i-hi 'usuwać brzeg (czyjegoś) płaszcza':

Pwt 23, 1 là yatazawwağ rağul imra'at 'abìhi wa-là yanzi dayl ridä'abīhi „Nie poślubi mężczyzna kobiety swojego ojca i nie usunie brzegu płaszcza swojego ojca".

Pwt 27, 20 mal'ūn man yud̄ăǧíu imra'at 'abīhi, li-'anna-hu yanzi' dayl ridä'abīhi „Przeklęty, kto spółkuje z kobietą swojego ojca, ponieważ usuwa brzeg płaszcza swojego ojca".

W innych przekładach idiom oddawany jest za pomocą wyrażeń z czasownikiem kašafa lub iktašafa (jako ekwiwalentu hebrajskiego czasownika gillå), którego dopełnieniem bliższym jest fraza dayl ('dolna część', 'spód', 'ogon', 'zakończenie,' 'skraj czegoś'; Wehr 1976: 316) 'abīhi 'swojego ojca'. Nie jest to w języku arabskim wyrażenie konwencjonalne (dayl określany jest zawsze rzeczownikami nieosobowymi, np. jak wyżej dayl ridä’brzeg płaszcza') i dlatego można je traktować jako dziwny neologizm pozbawiony charakteru wulgarnego, ale też niezrozumiały. W swoim dosłownym tłumaczeniu oddałam dziwaczność i niezrozumiałość tego arabskiego rozwiązania ${ }^{4}$ :

\section{kašafa dayla-hu 'odkrywać (czyjąś) dolną część'}

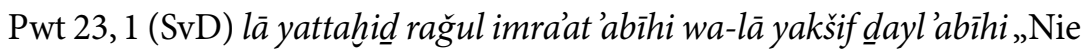
poślubi mężczyzna żony swojego ojca i nie odkryje dolnej części swojego ojca”.

Pwt 27, 20 (SvD) mal'ūn man yadțağíu ma'a imra'at 'abīhi li-anna-hu yakšifu dayl'abìhi „Przeklęty, kto spółkuje z kobietą swojego ojca, ponieważ odkrywa dolną część swojego ojca”.

Innym rozwiązaniem jest użycie rzeczownika sitr 'zasłona' jako dopełnienia bliższego czasownika kašafa lub iktašafa. Mamy tutaj do czynienia ze skonwencjonalizowaną metaforą oznaczającą ujawnienie czyjejś tajemnicy, czegoś ważnego lub/i intymnego.

\section{iktašafa sitra-hu 'odkrywać (czyjąś) zasłonę'}

Pwt 27, 20 (LAB) mal'ūn kull man yuḍ̄ğíu imra'at 'abīhi li-'anna-hu yakšifu sitr 'abīhi „Przeklęty jest każdy, kto spółkuje z kobietą swojego ojca, ponieważ odkrywa zasłonę swojego ojca”.

4 To ustalenie na podstawie rozmowy z dr. hab. Yousefem Sh'hadeh z Katedry Arabistyki UJ. 
W kolejnych tłumaczeniach użyto wyrażenia, które nie tyle oddaje znaczenie referencyjne omawianego idiomu, ile wprowadza ocenę nazwanego nim czynu za pomocą negatywnie wartościujących czasowników (z rzeczownikiem 'ab 'ojciec' jako dopełnieniem bliższym):

\section{'a'āba-hu 'zhańbić kogos'}

Pwt 23, 1 (ERV-AR) lā yağūzu li-'ahad 'an yatazawwağa zawğat 'abi-hi li-'anna hādā sa-yu'ību 'abā-hu „Nie uchodzi, żeby ktoś poślubił żonę swojego ojca, ponieważ to zhańbi jego ojca";

\section{'ahāna-hu 'upokorzyć kogoś'}

Pwt 27,20 (ERV-AR) mal'ūn kull man yu'äširu zawğat 'abì-hi li-'anna-hu yuhīnu 'abā-hu „Przeklęty jest każdy, kto współżyje z żoną swojego ojca, ponieważ upokarza swojego ojca";

\section{intahaka hurmata-hu 'naruszyć czyjąś nietykalność'}

Pwt 27, 20 (GNA) lā yatazawwağ rağul zawğat 'abīhi fa-yantahiku ḥurmat 'abīhi „Mężczyzna niech nie poślubia żony swego ojca, bo naruszyłby nietykalność swojego ojca".

Zamiast leksemów czasownikowych mogą w tych kontekstach występować wyrażenia ocenne z rzeczownikami: 'ihāna 'upokorzenie' czy też 'ār 'hańba' (który ponadto może nasuwać skojarzenie z przymiotnikiem 'ārin 'nagi', gdyż zapis ich obu w formie nieokreślonej bez wokalizacji jest taki sam: 'âr):

\section{ğalaba l-‘ār / 'atā bi-l-'ār la-hu 'przynosić komuś hańbę'}

Kpł 18, 7 (ERV-AR) là ta'ti bi-l-'âr li-'abì-ka bi-'an tu'äšira'umma-ka „Nie przynoś hańby swemu ojcu (tym, że współżyjesz ze swoją matką)!”;

Kpł 20, 11 (ERV-AR) 'in 'āšara rağul zawğat 'abì-hi, fa-'inna-hu qad ğalaba l-'âr lii-'abi- $h i$ „Jeśli mężczyzna współżyje z żoną swojego ojca, przynosi hańbę swojemu ojcu";

\section{'ār wa-'ihāna la-hu '(stanowić) hańbę i upokorzenie dla kogoś'}

Pwt 23, 1 (LAB) là yatazawwağ 'ahad 'armalat 'abīhi, li-'anna hādā 'ār wa-'ihāna li-'abīhi „Niech nikt nie poślubia wdowy po swoim ojcu, ponieważ jest to wstyd i upokorzenie dla jego ojca”.

\section{Hebrajskie wulgaryzmy}

W Biblii możemy natknąć się na wulgaryzmy, czyli ,jednostki leksykalne, za pomocą których mówiący ujawnia swoje emocje względem czegoś lub kogoś, 
łamiąc przy tym tabu językowe" (SPPiW: 15; także Maliszewski 2007: 55-56). Gdy z początkiem średniowiecza zaczęto wokalizować tekst Biblii hebrajskiej, wyrazy wulgarne uzupełniano samogłoskami ich eufemistycznych ekwiwalentów, których spółgłoski podawano na marginesie, dzięki czemu nie naruszano integralności świętego tekstu. Tego rodzaju słownictwo pojawia się głównie w partiach tekstu nacechowanych ekspresywnie (wypowiedzi postaci biblijnych). W partiach narracyjnych lub w objaśnieniach przepisów prawa występują wyłącznie eufemistyczne ekwiwalenty wulgaryzmów. Zauważmy, że obecność omówionego powyżej zabiegu może posłużyć za wskaźnik przynależności leksemu do sfery językowego tabu.

Innym sposobem unikania wyrażeń uznanych za niestosowne w tekście biblijnym było zastępowanie ich metonimiami lub metaforami:

\section{hinnam šolhim 'et hazzmora 'el 'appam 'podnoszą gałąź do swojego nosa'}

W Ez 8, 17 Bóg mówi, że ludzie obrażają go, wykonując gest nazwany tu bardzo wulgarnym wyrażeniem, które dosłownie tłumaczymy: 'podnosić gałąź do (czyjegoś) nosa', przy czym gałąź to skonwencjonalizowana metafora oznaczająca penisa (Piela 2007: 246 i literatura tamże). W Biblii hebrajskiej rzeczownik nos był pierwotnie określony zaimkiem dzierżawczym 1. osoby (appi 'mój nos') odnoszącym się do Boga, jednak uznano, że takie sformułowanie jest zbyt obraźliwe, i aby zmniejszyć stopień obelżywości, wprowadzono w to miejsce zaimek 3. osoby pl. (appam 'ich nos'), czyli zmieniono sens całej frazy z 'podnoszą ",gałąź' do mojego nosa' na 'podnoszą "gałąź" do swojego nosa' (KB: 273).

W przekładach arabskich pojawia się dosłowne tłumaczenie idiomu, nieoddające wulgarności oryginalnego wyrażenia, ale też niezrozumiałe bez przypisu. Hebrajski leksem zmora o znaczeniu dosłownym 'gałąź', a metaforycznym - 'penis' zostaje tu oddany m.in. za pomocą leksemu ġuṣn - 'gałązka', witka', 'odgałęzienie' (Wehr 1976: 675):

qarraba l-iguṣn 'ilā 'anfi-hi 'przysuwać gałązkę do (czyjegoś) nosa'

(GNA) hum yamla'ūna al-'arḍ ğawran wa-yutīiūna gadabì. 'unzur 'ilay-him yuqarribūna al-g்usn 'ila 'unüfi-him „Napełniają ziemię despotyzmem i wzbudzają mój gniew. Popatrz, jak przysuwają gałązkę do nosa [dosł. do swoich nosów]”. W przypisie znajdujemy objaśnienie, że: „Ten tekst wskazuje na pogański obyczaj" (s. 1044). 
SvD: qad mala'ū al-'arḍ zulman wa-ya'ūdūna li-'ig̀äzatī wa-ha hum yuqarribūna al-ġusn 'ila 'anfi-him „Napełnili ziemię niesprawiedliwością i znów wzbudzają mój gniew. Oto przysuwają gałązkę do (swojego) nosa”.

(JAB) mala'ù al-'ard 'unfan wa- 'àdū yushițūnanì wa-ha hum yuqarribūna al-gusn 'ilā 'unüfi-him” „Napełnili ziemię przemocą i znów wzbudzili mój gniew. Oto przysuwają gałązkę do nosa [dosł. do swoich nosów]”. Przypis informuje czytelników, że „nie możemy dokładnie określić znaczenia w.wym. praktyk".

Analogiczne rozwiązania odnajdujemy w tłumaczeniach Ez 8, 17 na język polski:

BWu: „Bo napełniwszy ziemię nieprawości, obrócili się ku drażnieniu mnie; a oto przykładają gałązkę do nosa swego”.

BPau: „Napełnili bowiem kraj przemocą i żeby Mnie znowu obrażać, przykładają gałązkę do nosa”. Dodano tu przypis sugerujący magiczne znaczenie dosłownie pojętego gestu 'przykładania gałązki do nosa': „być może chodzi o zwyczaj, który miał chronić przed profanacją aury wschodzącego słońca" (s. 1859).

BT: „Napełniają kraj ten przemocą i stale Mnie obrażają. I oto wciąż podnoszą gałązkę do nosa”. W BT także znajdujemy przypis wskazujący na domniemany związek z pogańskim obrzędem: „Obrzęd bliżej nieznany. Może naśladowanie irańskiej adoracji słońca, przy której trzymano gałązkę palmy przed ustami, by oddech nie kalał powietrza”.

Należy zaznaczyć, że w języku arabskim występuje dokładniejszy ekwiwalent hebrajskiego leksemu zmora - qaḍib ('gałązka,' 'witka,' 'pręt,', 'kijek', jak i 'prącie,' 'męski członek'; Wehr 1976: 771), którego ,anatomiczne” znaczenie nie jest obarczone wulgarnymi konotacjami ${ }^{5}$. Nie pojawił się on w żadnym z przytoczonych przekładów być może właśnie dlatego, by nie wywoływać „anatomicznych” skojarzeń. Nie posłużono się również etymologicznym, znaczeniowym i stylistycznym odpowiednikiem hebr. zmora - zubr'penis' (KB: 272-273). Można zatem domniemywać, że leksykalne wybory tłumaczy nie były w tym wypadku podyktowane ograniczeniami systemu językowego, lecz były decyzją o charakterze estetyczno-moralnym.

Także w języku polskim występują leksemy cechujące się analogiczną dwuznacznością, jak np. laska (SPPiW: 93), kij (SPPiW: 81-82), tyle tylko, że to drugie, nadbudowane znaczenie jest $\mathrm{w}$ tym przypadku obsceniczne

5 To ustalenie na podstawie rozmowy z dr. hab. Yousefem Sh'hadeh. 
i funduje wyrażenia o dużym stopniu wulgarności. Nie znajdują one, rzecz jasna, zastosowania w polskich przekładach Ez 8, 17.

Skojarzenie z pogańskimi praktykami (wskazane w przywołanych powyżej przypisach do polskich przekładów) zostaje wyrażone expressis verbis w tekście ERV-AR, gdzie występuje wyrażenie: waḍ'a 'aqrätan wataniyya $f i$ 'anfi-hi 'wkładać pogańskie kolczyki do nosa':

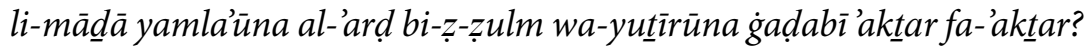
ha 'inna-hum yada'ūna 'aqrätan wațaniyya fī 'unūfi-him! „Dlaczego napełniają ziemię przemocą i coraz bardziej wzbudzają mój gniew? Bowiem wkładają pogańskie kolczyki do nosa!".

W LAB tłumaczeniem hebrajskiego idiomu jest wyrażenie niebędące idiomem w języku arabskim, stanowiące interpretację jego znaczenia, dalekie od stylistycznej adekwatności: qarraba kull ma huwa muntin fī haykal 'przysuwać wszystko, co cuchnie w świątyni':

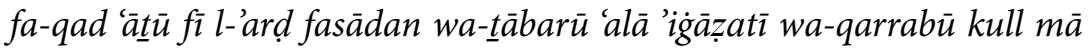
huwa muntin fì haykal̄ "Splamili ziemię zepsuciem i spowodowali moje rozwścieczenie. Przysuwają wszystko, co cuchnie w mojej świątyni”.

\section{maštin bqir 'sikający na ścianę'}

W kilku fragmentach ST (1 Krl 14, 10; $1 \mathrm{Krl} \mathrm{16,11;1} \mathrm{Krl} \mathrm{21,} \mathrm{21;} 2 \mathrm{Krl}$ 9, 8; $1 \mathrm{Sm} 25,22 ; 1 \mathrm{Sm} 25,34)$ pojawia się idiom maštin bqir mający w biblijnym hebrajskim charakter wulgaryzmu. Jego dosłowne znaczenie to: 'sikający na ścianę, a jego polskim odpowiednikiem, adekwatnym pod względem znaczenia leksykalnego [określenie niedorosłego mężczyzny], jak i stylu [wyrażenie lekceważenia, niechęci, pogardy], może być derywat 'szczyl'. Na przykład w tłumaczeniu Marka Pieli $1 \mathrm{Krl}$ 21,21 „wygładzę wszystkich mężczyzn z twojej rodziny, nie przepuszczę nawet najnędzniejszemu szczylowi” (Piela 2003: 206-207).

W najstarszych - pochodzących z XIX wieku - przywoływanych tu przekładach arabskich znajdujemy dosłowne tłumaczenie wspomnianego idiomu, które konsekwentnie występuje we wszystkich fragmentach, gdzie pojawia się on w oryginale:

SvD: $1 \mathrm{Krl}$ 21, 21 'aqta'u li-'Ah'äb kull bä'il bi-hä'it „wytnę Achabowi każdego sikającego po ścianie ( $b a \bar{i} i l$ - imiesłów czynny od czasownika $b a \bar{l} a$ 'oddawać mocz, sikać').

1 Sm 25, 22 'in abqaytu min kull ma la-hu [...] bäilan bi-hä’it ,jeśli zostawię z wszystkiego, co on ma [...] [choćby jednego] sikającego po ścianie”. 


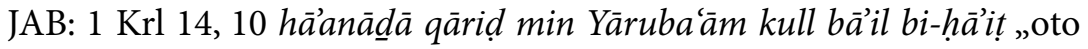
ja ukarzę z (rodziny) Jeroboama każdego sikającego po ścianie”. (Przypis informuje, że jest to „metafora wskazująca na mężczyznę”, s. 657).

Występowanie tego wyrażenia mającego charakter deleksykalizacji hebrajskiego idiomu maštin bqir jest ograniczone wyłącznie do tłumaczeń Biblii.

Jeśli chodzi o polskie przekłady, dosłowne tłumaczenie wspomnianego idiomu (np. $1 \mathrm{Krl}$ 21,21) występuje choćby w BWu: ,wytracę z Achab mokrzącego na ścianę”, czy w NBG: „zgładzę Ahabowi wszystko, co moczy ścianę". Tłumaczenia te są niezrozumiałe dla polskiego czytelnika, który faktu „moczenia ściany” (ponadto oddanego takimi środkami językowymi) nie skojarzy z młodym wiekiem mężczyzny. Zapewne z tego właśnie względu rozwiązanie to nie przyjęło się w polskiej tradycji translatorskiej. Może ono, co więcej, kojarzyć się z 'obszczymurkiem', jednak ten ostatni wyraz znaczy po polsku tyle co 'menel' czy 'pijaczek', natomiast cytowany fragment Biblii mówi o członkach znakomitego rodu.

W nowszych przekładach arabskich idiom maštin bqir oddawany jest najczęściej za pomocą pojedynczych leksemów: dakar osobnik płci męskiej, 'mężczyzna', 'samiec' (ekspresywnie nienacechowany) oraz rağul 'mężczyzna', 'człowiek'. Nie są one precyzyjnymi ekwiwalentami semantycznymi wspomnianego idiomu, który odnosi się jedynie do mężczyzn w młodym wieku:

$1 \mathrm{Krl}$ 21, 21 (GNA): ’ubìdu naslaka wa-aqta'u kull dakar fì-hi „wytępię twoje potomstwo i wytnę w nim każdego mężczyznę";

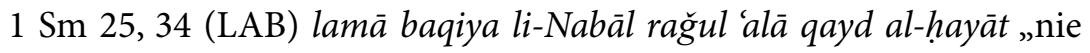
zostałby Nabalowi przy życiu żaden mężczyzna”.

Przytaczane tutaj nowsze przekłady arabskie wykorzystują te same rozwiązania także w innych fragmentach, w których występuje wyrażenie

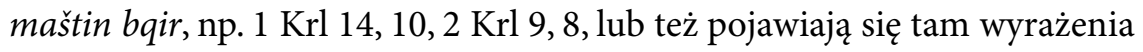
o różnym stopniu bliskoznaczności, jak choćby w ERV-AR:

1 Sm 25, 22: sa’aqtulu kull fard fí 'àilat Nābāl „zabiję każdego członka rodziny Nabala";

$1 \mathrm{Krl}$ 16, 11 lam yabqa min-hum 'ahad „nie pozostanie z nich nikt”.

Leksem 'mężczyzna' (niekoniecznie młody) pojawia się także w polskich przekładach, np. w BPau (1 Sm 25, 34: „Nabal nie miałby już u siebie ani jednego mężczyzny"). Ta sama BPau stosuje także wyrażenie 'męski potomek', 
np. $2 \mathrm{Krl}$ 9, 8: „wytępię Achabowi w Izraelu każdego męskiego potomka aż do ostatniego".

$\mathrm{W}$ innych polskich przekładach pojawiają się pojedyncze leksemy lub krótkie frazy oznaczające młodego mężczyznę, np. w BT: 1 Krl 21,21: „wytępię z domu Achaba nawet chłopca”. Przypis objaśnia, że wyraz „chłopiec” jest dosłownym tłumaczeniem wyrażenia „który moczy ścianę” (s. 336).

\section{mahra'a 'ubikacja'}

W $2 \mathrm{Kr}$ 10, 27 występuje hebrajski leksem mahra'a będący bardzo ordynarnym określeniem ubikacji - jest to nazwa miejsca derywowana od wulgarnego rzeczownika hara'łłajno'. Na potrzeby głośnej lektury w bóżnicy podano na marginesie inny wariant, eufemizm moṣa'a 'wychodek', czyli miejsce, do którego się wychodzi. Przywołany tu fragment mówi o tym, że po zburzeniu świątyni Baala miejsce to zamieniono $\mathrm{w}$ ubikację. Intencją użycia takiego właśnie określenia była rzecz jasna pogarda dla kultu bożków, zwłaszcza kultu Baala (przeciwstawienie się mu jest częstym motywem starotestamentowym).

Etymologicznym odpowiednikiem hebrajskiego maḥra'a w języku arabskim jest leksem mahra’a, który oznacza kloakę, ,miejsce, gdzie wydalane są ekskrementy, nieczystości" (Lane 1968: 715). Dodajmy, że słownik Lane’a powołuje się wyłącznie na słowniki średniowieczne, natomiast słowniki współczesnego języka arabskiego nie notują takiego hasła ${ }^{6}$. Archaiczność tego leksemu mogłaby przemawiać za wykorzystaniem go w tłumaczeniu, którego przedmiotem jest przecież tekst starożytny, tym bardziej że jest on stylistycznym ekwiwalentem hebrajskiego wulgaryzmu, jako że jego motywację słowotwórczą stanowi używany do dziś wulgarny rzeczownik harä' 'ekskrementy', 'gówno' (Danecki, Kozłowska: 314).

Przytoczone w niniejszym artykule arabskie tłumaczenia Biblii nie stosują jednak tego leksemu - dokonując autocenzury (Tokarz 2007: 10-12), sięgają po inne środki językowe, niebędące wulgaryzmami. Znajdujemy w nich leksemy w zasadzie stylistycznie neutralne. W SvD, LAB, GNA występuje leksem mazbala (nazwa miejsca, gdzie znajdują się 1.'śmieci,'odpadki' - zubāla, czyli śmietnik, lub 2. zibl 'obornik', 'gnój', czyli 'gnojowisko'; Wehr

6 Nieznajomość tego słowa przez współczesnych użytkowników języka arabskiego poświadczył dr hab. Yousef Sh'hadeh. 
1976: 373). Leksem ten nie ma wulgarnego charakteru, a jego negatywne konotacje wynikają jedynie ze skojarzenia $\mathrm{z}$ funkcją tego miejsca:

(LAB) hadamū al-ma 'bad wa-ḥawwalū-hu 'ilā mazbala „zburzyli świątynię i zamienili ją w śmietnik".

Inny ekwiwalent hebrajskiego mahra'a to neutralny stylistycznie leksem mirhạạ 'toaleta,' 'ubikacja,' 'szalet' (pod względem słowotwórczym jest to nazwa środka czynności - to, co służy do spłukiwania, mycia: 'sedes'), zaświadczony w JAB: hadamū bayt al- Ba'l wa-ğa'alū-hu mirhạdan „zburzyli świątynię Baala i zrobili z niej ubikację". Z kolei w ERV-AR pojawia się w tym miejscu fraza mirhậ 'āmm 'publiczny szalet'.

W polskich przekładach, podobnie jak w przekładach arabskich, występują określenia pejoratywne, lecz nie wulgarne: wychody (BWu) „Zbór też Baalów skazili i poczynili z niego wychody”; kloaki (BT) „Wreszcie zburzyli świątynię Baala i zamienili ją na kloaki”; śmietnik (BPau) „Świątynię zburzyli, zamieniając ją w śmietnik".

\section{Podsumowanie}

Z powyższych analiz wynika, że tłumaczom Biblii na język arabski, jak również na język polski przeważnie nie udaje się uzyskać ekwiwalencji dynamicznej w tłumaczeniu wyrażeń idiomatycznych, zwłaszcza wulgaryzmów. Przestrzegając zasad tabu językowego, wyrażenia idiomatyczne tłumaczą albo z zachowaniem ekwiwalencji formalnej (co czyni je najczęściej niezrozumiałymi dla odbiorcy), albo zastępują je wyrazami lub wyrażeniami o podobnej referencji, lecz o odmiennej wartości stylistycznej. Ekspresywne nacechowanie tekstu można by uzyskać, wplatając w arabski język literacki fragmenty w dialektach, jednak takiej praktyki się nie stosuje.

\section{Literatura}

Al-Absi M., 2018, The Concept of Nudity and Modesty in Arab-Islamic Culture, „European Journal of Science and Technology”, 14, 2, s. 25-34.

Danecki J., 2000, Współczesny język arabski i jego dialekty, Warszawa.

Ellingworth P., Mojola A.O., 1986, Translating euphemisms in the Bible, „Bible Translator", 37, 1, s. 139-143. 
Griffith S.H., 2013, The Bible in Arabic: The Scriptures of the "People of the Book" in the Language of Islam, Princeton-Oxford.

Khan G., 2006, Judaeo-Arabic, [w:] Encyclopedia of Arabic Language and Linguistics, t. 2, K. Versteegh (red.), Leiden-Boston, s. 526-536.

Krawczyk-Tyrpa A., 2001, Tabu w dialektach polskich, Bydgoszcz.

Majewski M., 2013, Jak przekłady zmieniają sens Biblii... O teorii i praktyce tłumaczenia Biblii, Kraków, https://upjp2.academia.edu/MarcinMajewski (dostęp: 3.03.2019).

Maliszewski J., 2007, Wulgaryzmy - tabu w pracy tłumacza, [w:] Tabu w przekładzie, P. Fast, N. Strzelecka (red.), Katowice-Częstochowa, s. 41-59.

Nida E.A., 1964, Toward a Science of Translating, Leiden.

Nida E.A., Taber Ch.R., 1969, The Theory and Practice of Translation, Leiden.

Pearson J.D., 1986, Al-Kur'ān, [w:] The Encyclopaedia of Islam, t. 5, C.E. Bosworth et al. (red.), Leiden, s. 400-432.

Piela M., 2003, Grzech dosłowności we współczesnych polskich przekładach Starego Testamentu, Kraków.

Piela M., 2007, Jakiego przekładu Biblii hebrajskiej brakuje w Polsce?, „Studia Judaica", 10, 2(20), s. 235-250.

Tokarz B., 2007, Tabu i autocenzura w przekładzie, [w:] Tabu w przekładzie, P. Fast, N. Strzelecka (red.), Katowice-Częstochowa, s. 7-23.

Versteegh K., 1997, The Arabic Language, New York.

\section{Biblie}

\section{Biblia hebrajska}

Elliger K., Rudolph W. (red.), 1984, Biblia Hebraica Stuttgartensia, wyd. 2 popr. przez W. Rudolpha i H. P. Rügera, Stuttgart.

\section{Biblie arabskie}

Smith and van Dyke Arabic Bible (SvD), 1998: Al-kitāb al-muqaddas 'ay kutub al-'ahd al-qadīm wa-l-'ahd al-ğadīd, Dār al-kitāb al-muqaddas fī aš-Šarq al-'Awsaṭ. Jesuit Arabic Bible (JAB), 1986: Al-kitāb al-muqaddas, Bejrut.

Arabic Life Application Bible (LAB), 2002: At-tafsīr at- taṭbīqiyy li-l-kitāb al-muqaddas, Kair.

Good News Arabic Bible (GNA), 1995: Al-kitāb al-muqaddas 'ay kutub al-'ahd al-qadīm wa-l-'ahd al-ğadīd. At-tarğama al-'arabiyya al-muštaraka min al-lug̣āt al-'aṣliyya, Dār al-kitāb al-muqaddas fī aš-Šarq al-'Awsaṭ. 
Arabic Bible: Easy-to-Read Version (ERV-AR): https://www.biblegateway.com/ versions/Arabic-Bible-Easy-to-Read-Version-ERV-AR/ (dostęp: 2.02.2019).

Biblie polskie:

Biblia Paulistów (BPau): Pismo Święte Starego i Nowego Testamentu. Najnowszy przekład z języków oryginalnych z komentarzem, 2008.

Biblia Tysiąclecia (BT): wyd. 3, 1980, Poznań.

Biblia Jakuba Wujka (BWu): http://biblia-online.pl/ (dostęp: 10.04.2021).

Nowa Biblia Gdańska (NBG): http://biblia-online.pl/ (dostęp: 10.04.2021).

\section{Słowniki}

Brown F., Driver S.R., Briggs Ch.A., 1997, The Enhanced Brown-Driver-Briggs Hebrew and English Lexicon. With an Appendix containing the Biblical Aramaic (BDB), Peabody.

Danecki J., Kozłowska J., 1996, Słownik arabsko-polski, Warszawa.

Grochowski M., 1995, Słownik polskich przekleństw i wulgaryzmów (SPPiW), Warszawa.

Koehler L., Baumgartner W., 1994, The Hebrew and Aramaic Lexicon of the Old Testament (KB), t. 1, W. Baumgartner, J.J. Stamm (rewizja), M.E.J. Richardson (tłum.), Leiden.

Lane E.W., 1968, An Arabic-English Lexicon, t. 2, Beirut.

Wehr H., 1976, A Dictionary of Modern Written Arabic, Ithaca.

\section{Linguistic taboo in Arabic translations of the Bible Summary}

Discussing selected solutions present in contemporary translations of biblical texts into Arabic, this article is an extension of Marek Piela's research on the translation of the Hebrew Bible into Polish. I analyse lexemes and expressions that belong to the taboo sphere and thus demand the use of premeditated linguistic means in translation.

The Bible verses studied in the article indicate that - when translating lexemes belonging to the taboo sphere - Arab translators follow the rules and avoid words naming God (Jahveh $\rightarrow$ Ar-rabb 'Lord') and body parts or objects having physiological connotations (vulg. mahra'a - 'privy' $\rightarrow$ neutral mazbala - 'dump'). Vulgar idioms are never translated as such, probably also due to compliance with the rules of linguistic taboo. Translators adopt various solutions in this respect. They translate 
individual elements of expressions literally, which leads to the unintelligibility of the resulting phrase (maštin bqir - 'pissing on a wall' - a vulgar and scornful term for a young male $\rightarrow b \bar{a} i l b i-h \bar{a} i t \underline{t}$ - 'pissing on a wall' - with no added secondary meaning). Sometimes vulgar expressions are rendered with equivalents interpreting their senses or functions. For instance, an expression naming a very insulting gesture šålah 'et hazzmora 'el 'appo - lit. 'to rise a twig up to one's nose' - is translated as wada'a 'aqrātan wataniyya fí 'anfi- $h i$ - 'to put pagan earrings into one's nose'. Idioms which euphemistically render tabooed contents tend to be translated literally, e.g. gillå 'erua - 'expose nudity' - a euphemism for sexual intercourse $\rightarrow$ kašafa 'awra 'expose nudity'; in this case the Arabic equivalent refers to some other sinful and tabooed act. Other solutions include rendering referential meaning substituted with some evaluative expression (gillå kånåf - 'to take off one’s clothes' - a euphemism for sexual intercourse $\rightarrow$ 'ahāna - 'to humiliate').

Concluding, it can be said that in most cases Arabic Bible translators do not manage to obtain dynamic equivalence in translating idioms, particularly the vulgar ones. Following the rules of linguistic taboo, they maintain formal equivalence or use expressions with similar referential meaning but of a different stylistic value.

Keywords: the Bible, Arabic translations of the Bible, linguistic taboo, euphemisms, vulgarisms

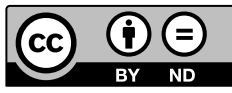

